\title{
Growth rate variability and lipofuscin accumulation rates in the blue crab Callinectes sapidus
}

\author{
Se-Jong Ju, David H. Secor, H. Rodger Harvey* \\ Chesapeake Biological Laboratory, University of Maryland Center for Environmental Science, PO Box 38, Solomons, \\ Maryland 20688, USA
}

\begin{abstract}
To better understand growth and age-pigment (lipofuscin) accumulation rates of the blue crab Callinectes sapidus under natural conditions, juveniles (33 to $94 \mathrm{~mm}$ carapace width) were reared in outdoor ponds for over $1 \mathrm{yr}$. Growth rates, measured by carapace width, during summer and fall exceeded all those reported in the literature; the initial carapace width of $59 \pm 14 \mathrm{~mm}$ (mean $\pm \mathrm{SD}$ ) increased to $164 \pm 15 \mathrm{~mm}$ within a 3 mo period. No growth occurred during winter months (November to April) at low water temperatures. Growth rates of crabs in ponds were substantially higher (von Bertalanffy growth parameter $K=1.09$ ) than those of crabs held in laboratory environments, and than rate estimates for natural populations of mid-Atlantic blue crabs. Model comparisons indicated that seasonalized von Bertalanffy growth models $\left(\mathrm{r}^{2}>0.9\right)$ provide a better fit than the non-seasonalized model $\left(r^{2}=0.74\right)$ for pond-reared crabs and, by implication, are more appropriate for field populations. Despite growth rates that varied strongly with season, lipofuscin (normalized to protein concentration) accumulation rate was nearly constant throughout the year. Although the lipofuscin level in pond-reared crabs was significantly correlated with size (carapace width), it was more closely correlated with chronological age. Lipofuscin accumulation rates were also similar to those observed for laboratory-reared crabs, despite very large differences in growth rates and temperature regimes. The constancy of normalized-lipofuscin accumulation rates of blue crabs across seasons and environmental conditions suggests that lipofuscin concentration can be a more robust indicator of age than carapace width alone.
\end{abstract}

KEY WORDS: Blue crab · Callinectus sapidus $\cdot$ Age and growth $\cdot$ Carapace width $\cdot$ Lipofuscin $\cdot$ Age pigment $\cdot$ Eye-stalk $\cdot$ Chesapeake Bay

\section{INTRODUCTION}

Although the blue crab Callinectes sapidus is an economically and ecologically important species in many temperate estuaries, growth, longevity, and frequency of spawning are not well understood. In contrast to fishes, for which scales or otoliths can provide specific indices of growth and age (Hjort \& Lea 1914, Secor et al. 1995), understanding growth and age structure of crustaceans is particularly difficult because they lack permanent hard structures. Crustaceans periodically molt their calcareous exoskeleton to accommodate

*Corresponding author. E-mail: harvey@cbl.umces.edu future growth, and in the process abandon all external evidence of age or previous size. A further complication is that carapace size, the most frequently used measure of growth, is a discontinuous function over time and is influenced by salinity, temperature, molting frequency, food quality, and life stage of the individual (Millikin \& Williams 1984, Welch \& Epifanio 1995, Smith 1997, Fisher 1999). For crustaceans such as the blue crab, modal analysis of length-frequency data is often used in lieu of direct measures of ageing and growth (e.g. Rothschild et al. 1992).

An accurate growth estimate is fundamental to any assessment of population demographics. Unfortunately, length-based methods are inherently imprecise for the blue crab and not often appropriate for deter- 
mining growth rate (Smith 1997). Mark-recapture studies have been conducted to support estimates of growth rate and age, but have had limited success as many tags are lost during molting (Fannaly 1978, van Montfrans et al. 1986, Fitz \& Wiegert 1991). Although growth estimates for blue crabs remain scant, and principally derive from laboratory studies with caged individuals, they are used for stock assessments (Rothschild et al. 1992, Rugolo et al. 1998). Several approaches have attempted to apply alternative growth models for crustaceans based on the intermolt period (Smith 1997) or temperature degree days (Curry \& Feldman 1987). These modeling efforts have also been constrained by the lack of empirical measures of the intermolt period and torpor temperature (minimum temperature for molting), respectively. It is apparent that a better understanding of growth dynamics for blue crabs can significantly improve the understanding of their population structure and lead to more precise stock assessments.

The critical need for age-structure data for blue crab populations has led to alternative methods of age determination. Among the most successful are biochemical and histological approaches to measure the suite of condensation products (termed 'lipofuscins', LF) which accumulate in post-mitotic tissue as a consequence of cellular peroxidation reactions (see review by Gutteridge 1987). The accumulation of LF has been used as an alternative to conventional morphometric age-determination techniques for several crustaceans, including lobsters (Belchier et al. 1994, Sheehy et al. 1996, Wahle et al. 1996), crayfish (Sheehy 1992, Belchier et al. 1998), prawns (Sheehy et al. 1995), and krill (Ettershank \& George 1984, Nicol et al. 1991). A modified biochemical approach whereby the concentration of LF is normalized to tissue protein has also proven successful for the blue crab Callinectes sapidus (Ju et al. 1999), but established a relationship between chronological age and LF level for only a 6 mo period in the laboratory. There is evidence that LF accumulation is associated with metabolic rate (Sohal 1981, Katz et al. 1984, Clarke et al. 1990, O'Donovan \& Tully 1996), and thus its accumulation rate may be affected by environmental factors (i.e. temperature, food, space, etc.). Thus, it is important to examine the growth and LF accumulation rate of blue crabs reared under more natural environmental conditions over longer time periods. Here, we report rates of blue crab growth as carapace width (CW) and normalized-lipofuscin (LF index) accumulation in outdoor ponds over longer time intervals which more closely mimic natural conditions. This rearing study also provides information on seasonal growth patterns among individuals and cohorts spawned in different seasons (i.e. spring vs fall), which can aid the prediction of crab growth and recruitment to the fishery.

\section{MATERIALS AND METHODS}

Pond rearing. In July 1998, a sample of juvenile Callinectes sapidus (size range, $\mathrm{CW}=33$ to $94 \mathrm{~mm}$; $58.9 \pm 14.2 \mathrm{~mm}[$ mean $\pm \mathrm{SD}], \mathrm{n}=49$ [female $=20$, male $=29$ ] representing the fall cohort of 1997 was collected from the mouth of the Patuxent River. Blue crabs spawn continuously from spring to fall in the Chesapeake Bay region (van Engel 1958, Jones et al. 1983, Johnson 1995). Although the major mode of settlement by post-larvae (megalopae) occurs in July/ August, substantial settlement continues until November (van Montfrans et al. 1990, 1995). Crabs used in this study were assumed to have originated from the fall spawning (September) based on their size (e.g. van Engel 1958). A sub-set of these were immediately sacrificed and analyzed, the other crabs were introduced into a 0.5 ha large and $2.0 \mathrm{~m}$ deep outdoor pond at Horn Point Laboratory (Cambridge, Maryland). The pond received a constant flow of screened ambient seawater (mean salinity $=10 \%$ ) from the Choptank River over the experimental period. Potential predators (cannibalism excepted) were excluded. The main prey available were abundant small fishes Fundulus heteroclitus and F. majalis and the brackishwater clam Rangia cuneata. At 3 to 6 mo intervals, the CW (including lateral spines) of individuals captured in pots was measured and a subset sacrificed for LF extraction and measurement. A second cohort of juveniles (size range, $\mathrm{CW}=54$ to $85 \mathrm{~mm} ; 59.5 \pm 7.33 \mathrm{~mm}, \mathrm{n}=36$ [female $=15$, male $=21$ ] representing the summer cohort of 1998 (assumed to have originated from the June/July spawning (i.e. July/August settlement) was collected in March 1999 from Fishing Bay (at the eastern shore of the mesohaline Chesapeake Bay) and introduced into a second replicate pond to estimate growth rate alone.

Seasonal growth and LF index accumulation rates were estimated for mid-dates between sampling events by dividing CW and LF index increments by the time elapsed between sampling dates. For the pond studies, the mid-spring, late-summer, late-winter, and latespring growth and accumulation rates correspond to the time increments 3 March-3 July, 5 August5 November, 6 November-5 May, and 6 May-17 August, respectively.

Individuals reared in ponds were compared to a group of juveniles (size range, $\mathrm{CW}=41$ to $95 \mathrm{~mm}$; $62.3 \pm 12.5 \mathrm{~mm}, \mathrm{n}=45$ [female $=25$, male $=20$ ] collected in the summer of 1997 and reared for a 6 mo period in the laboratory as described by Ju et al. (1999). In that study, crabs were held in individual cages 


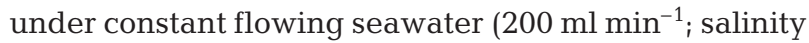
ranging from 10 to $15 \%$ ) at constant $\left(20^{\circ} \mathrm{C}\right)$ or ambient $\left(24 \pm 4^{\circ} \mathrm{C}\right)$ temperatures; juveniles were fed small pieces of frozen fish (typically Brevoortia tyrannus) every other day, and size (CW) and LF were measured monthly; at regular intervals $(0,1,2,3,5$ and $6 \mathrm{mo})$, laboratory-reared crabs were sacrificed and the LF contents were measured using a modified method of Ju et al. (1999) as described below.

Analysis of extractable LF. Crabs collected from the pond were anesthetized on ice prior to being sacrificed. After morphological measurement, eye-stalk tissues were carefully dissected and extracted for LF determination (Ju et al. 1999). Briefly, each excised tissue was transferred to a $4 \mathrm{ml}$ amber vial for solvent extraction of LF. The analytical procedure for measurement of fluorescence intensity was modified slightly to improve sensitivity and to accommodate higher sample numbers by switching from individual sample detection (Hitachi 4500 scanning fluorescence spectrophotometer) to a flow-cell fluorescence spectrophotometer (Waters 474 Scanning Fluorescence Detector). Volumes of $10 \mu \mathrm{l}$ from each extract were injected by an auto-sampler (Waters 717 Plus Autosampler) with me-

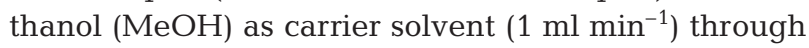
the flow cell. Fluorescence intensity was measured at a maximum emission wavelength of $405 \mathrm{~nm}$ using a maximum excitation at $340 \mathrm{~nm}$ at constant temperature $\left(\mathrm{ca} 10^{\circ} \mathrm{C}\right)$. Fluorescence intensities of identical extracts using these detectors were significantly correlated $(\mathrm{r}=0.89, \mathrm{n}=42 ; \mathrm{p}<0.001)$ and values calibrated with those obtained by prior analysis.

To provide a quantitative measure of LF in tissue, fluorescence intensities of extractable LF were calibrated versus quinine sulfate (in $0.1 \mathrm{~N} \mathrm{H}_{2} \mathrm{SO}_{4}$ ) and normalized to protein content of extracted tissues measured by the modified bicinchoninic acid (BCA) assay described by Nguyen \& Harvey (1994). Although fluorescence intensity itself can be accurately calibrated against external standards, LF per unit tissue volume has often relied on wet or dry weight of small tissue samples, either before or after extraction (e.g. Ettershank \& George 1984). Such measures are inherently variable and differ among tissue types and processing methods. Our use of cellular protein as a basis for measurement of extractable LF concentrations eliminates many of these difficulties. Rather than wet weight or other mass measures, protein provides a representative value of cellular material extracted over a wide range of tissue sizes, with the protein-normalized LF content expressed as LF index or normalized-LF ( $\mu \mathrm{g}$-LF content $\mathrm{mg}^{-1}$ protein).

Statistical analyses. All data were natural log-transformed before statistical analyses to satisfy assumptions for homogeneity of variances and normality of residuals. Analysis of variance (ANOVA) was perfor- med to determine whether the CW and eye-stalk LF index were affected by time; contrasts of CW and the LF index among sampling dates used the protected Fisher's least significant difference (LSD) test. Regression analysis determined whether growth and normalized-LF accumulation rate differed between laboratory- and pond-reared crabs (Littell et al. 1999). All statistical analyses were performed using SAS (Version 6.12). The von Bertalanffy growth model (von Bertalanffy 1938) was used to estimate growth rates for laboratory- and pond-reared crabs. Von Bertalanffy growth parameters $L_{\infty}$ (asymptotic maximum length) and $\mathrm{K}$ (annual growth rate, or the rate at which individuals approach $L_{\infty}$ ) were compared with those reported previously in the literature. To take seasonality into account (seasonal growth fluctuations are very marked in decapod crustaceans living in temperate regions), seasonalized von Bertalanffy growth models (by FiSAT: Gayanilo et al. 1996) were also fitted for pond-reared crabs. The seasonalized von Bertalanffy growth function can be described as:

$L(t)=L_{\infty}\left[1-\exp \left\{-\mathrm{K}^{\prime}\left(t-t_{0}\right)-\left(\mathrm{CK}^{\prime} / 2 \pi\right)\left(\sin 2 \pi\left(t-t_{\mathrm{s}}\right)-\sin 2 \pi\left(t_{0}-t_{\mathrm{s}}\right)\right)\right\}\right]$

where $\mathrm{K}^{\prime}=$ annual growth coefficient $\left(\mathrm{yr}^{-1}\right), t_{0}=$ month of spawning, $t_{\mathrm{s}}=$ the time of the year when the growth rate is highest; $\mathrm{C}=$ the amplitude of the seasonality factor, which ranges between 0 and 1 (i.e. for values of $\mathrm{C}$ close to 0 no seasonality occurs, for values close to 1 the amplitude is maximal).

\section{RESULTS}

Juvenile Callinectes sapidus $\leq 1 \mathrm{yr}$ old (mean CW $=$ $59 \mathrm{~mm} ; \mathrm{n}=49$ ) grew rapidly and reached adult size (mean CW $=164 \mathrm{~mm} ; \mathrm{n}=11$ ) within 3 mo (by August to October) (Fig. 1). Growth ceased during winter as temperature declined. Growth from May to August for larger individuals was much slower than for juveniles in the previous summer and fall. Both carapace width and LF index in the eye-stalk increased significantly over the experimental duration $($ ANOVA $F=$ $52.06(\mathrm{df}=3,17)$ and $21.81(\mathrm{df}=3,17)$, respectively; $p<0.001$ ). Seasonal comparisons of CW revealed no significant change after the first growth season (November 1998 to August 1999), whereas the LF index increased significantly through all seasons until the last time point sampled (Fig. 1). The minimum time period resolved by changes in the LF index from the pond-rearing experiment was approximately 3 mo.

The seasonal growth rates of pond-reared crabs estimated from CW increments corresponded well with changes in water temperature (Fig. 2). Growth rates were maximal during the first year of growth, with no 
Table 1. Parameter estimates of von Bertalanffy growth model $\left[L_{t}=L_{\infty}\left(1-\mathrm{e}^{-\mathrm{K}\left(t-t_{0}\right)}\right)\right]$ for Callinectes sapidus

\begin{tabular}{|c|c|c|c|c|}
\hline Study site & Max. size $\left(L_{\infty}, \mathrm{mm}\right)$ & Growth rate $\left(\mathrm{K}, \mathrm{yr}^{-1}\right)$ & Initial time $\left(t_{0}=y r\right)$ & Source \\
\hline \multicolumn{5}{|l|}{ Chesapeake Bay } \\
\hline laboratory and field & 178 & 0.51 & 0 & Rothschild et al. (1992) \\
\hline Chesapeake Bay & 262.5 & 0.59 & 0.12 & Rugolo et al. (1998) \\
\hline Chesapeake Bay ${ }^{a}$ & 191.9 & 0.64 & 0.31 & Smith (1997) \\
\hline \multicolumn{5}{|l|}{ Chesapeake Bay } \\
\hline laboratory & 180.9 & 0.49 & 0.08 & This study \\
\hline pond & $240^{\mathrm{b}}$ & 1.09 & 0.40 & This study \\
\hline Louisiana $^{a}$ & 175.9 & 1.45 & 0.13 & Smith (1997) \\
\hline \multicolumn{5}{|l|}{ Delaware Bay } \\
\hline Trawl survey & 234.7 & 0.75 & -0.2 & Helser \& Kahn (1999) \\
\hline
\end{tabular}

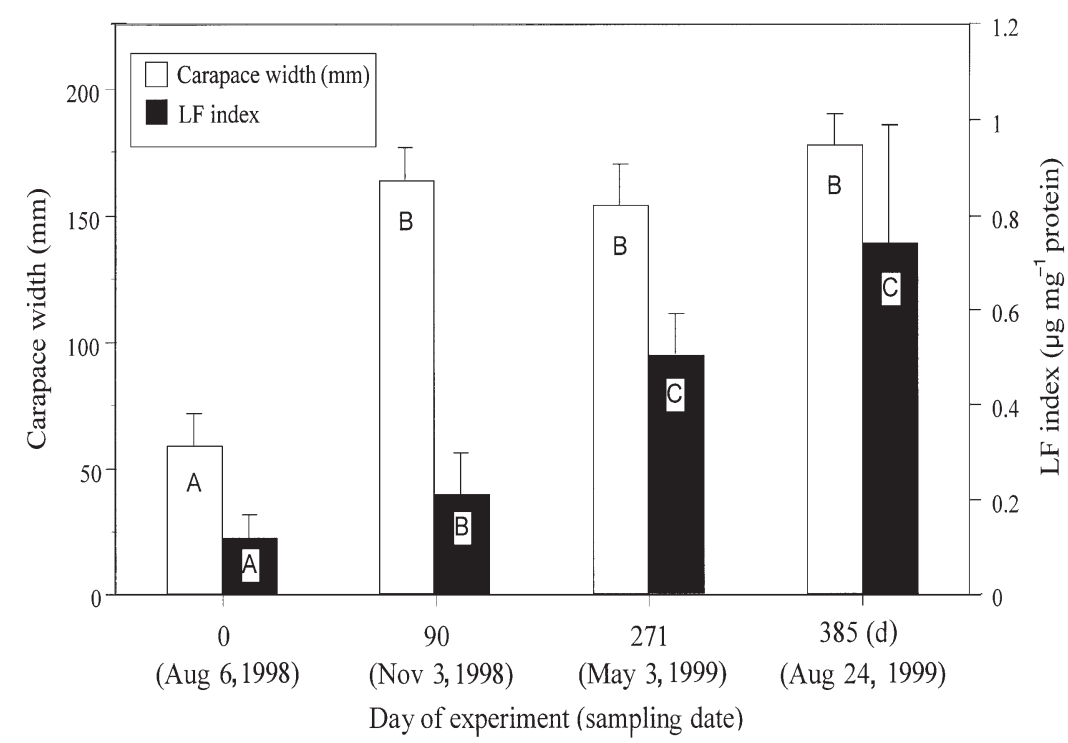

Fig. 1. Changes in size and normalized-lipofuscin (LF) index with time $(0,90$, 271, and $385 d_{i} n=8,5,3$ and 5, respectively) for juveniles collected in August 1998 from Patuxent River and reared in outdoor ponds. All results are means \pm 1 SD. Bars sharing same letter(s) are not statistically different: protected Fisher's LSD test, $p=0.05$

Table 2. Parameter estimation for seasonalized von Bertalanffy functions (Eq. 1) modeled by size (carapace width, $\mathrm{mm}$ ) of pond-reared crabs. $\mathrm{K}^{\prime}$ : annual growth coefficient $\left(\mathrm{yr}^{-1}\right) ; t_{0}$ : time of spawning, $t_{\mathrm{s}}$ : time of the year when growth rate is highest; C: coefficient of seasonal oscillation

\begin{tabular}{|lcccccc|}
\hline Rearing experiment & $L_{\infty}(\mathrm{mm})$ & $\mathrm{K}^{\prime}\left(\mathrm{yr}^{-1}\right)$ & $t_{0}(\mathrm{yr})$ & $\mathrm{C}$ & $t_{\mathrm{s}}$ & $\mathrm{r}^{2}$ \\
\hline $\begin{array}{l}\text { Pond-98 } \\
\text { (Aug 1998-Aug 1999) }\end{array}$ & 207.5 & 1.71 & 0.31 & 1.0 & 0.01 & 0.90 \\
$\begin{array}{l}\text { Pond-99 } \\
\text { (Mar 1999-Apr 2000) }\end{array}$ & 207.5 & 1.19 & 0.15 & 0.94 & 0.01 & 0.93 \\
\hline
\end{tabular}

growth in winter at low temperatures. Normalized-LF accumulation rates estimated for the same individuals were constant over seasons and years regardless of seasonal variations in growth rate. Growth rates as measured by the non-seasonalized von Bertalanffy growth coefficient $\mathrm{K}$ (rate at which asymptotic size is attained) varied from 0.49 to 1.45 , depending on experimental conditions or study area (Table 1). The growth coefficient for pond-reared crabs (1.09) is much higher than previous estimates for Chesapeake Bay (0.51 to 0.64) and nearby Delaware Bay (0.75) crabs (Fig. 3). Pond-reared crabs also grew at substantially higher rates than crabs in laboratory environments (Table 1, Fig. 3). For pond-reared crabs, the seasonalized von Bertalanffy growth models $\left(r^{2}>0.9\right)$ provide a better fit than the non-seasonalized model $\left(r^{2}=0.74\right)$ (Fig. 4). Interestingly, growth coefficients $\left(K^{\prime}\right)$ measured by the seasonalized model (Eq. 1) for 2 different sets of pond-reared crabs were slightly different $\left(K^{\prime}=1.71\right.$ and 1.19 for crabs reared from August 1998 to August 1999 and crabs reared from March 1999 to April 2000, respectively) (Fig. 4, Table 2), but not statistically different (regression analysis; $\mathrm{p}>0.05$ ).

Despite differences in CW, the LF index in eye-stalks showed no significant differences between laboratoryand pond-reared crabs (Table 3). 
Table 3. Results of regression analysis for rearing condition effects (laboratory [ $\mathrm{n}=34$ ] vs pond $[\mathrm{n}=21]$ ) on size (carapace width, $\mathrm{mm}$ ) and lipofuscin index ( $\mu \mathrm{g} \mathrm{mg}^{-1}$ protein) in Callinectes sapidus. All data were $\log _{\mathrm{e}}$-transformed before analysis. A: slope $( \pm 95 \% \mathrm{CL}) ; \mathrm{B}$ : intercept $( \pm 95 \% \mathrm{CL}) ; \mathrm{p}$ : probability of Type II error; Adj. $\mathrm{r}^{2}$ : adjusted regression coefficient; Z: slope comparisons between laboratory vs pond; NS: not significant $(\mathrm{p}>0.05)$

\begin{tabular}{|lcccl|}
\hline Regression & \multicolumn{1}{c}{ A } & B & Adj. $\mathrm{r}^{2}$ & $\mathrm{p}$ \\
\hline Size (CW) vs Time & & & & \\
Laboratory & $0.68 \pm 0.037$ & $4.15 \pm 0.064$ & 0.29 & 0.0001 \\
Pond & $0.58 \pm 0.021$ & $4.54 \pm 0.161$ & 0.59 & 0.001 \\
Z & & & & 0.0001 \\
LF index vs Time & & & \\
Laboratory & $0.113 \pm 0.059$ & $-2.319 \pm 0.210$ & 0.30 & 0.0001 \\
Pond & $0.143 \pm 0.036$ & $-2.057 \pm 0.257$ & 0.78 & 0.0001 \\
Z & & & & NS \\
& & & & \\
\hline
\end{tabular}

Because there was no effect of rearing condition (laboratory vs pond) on the normalized-LF (or LF index), data were pooled to estimate normalized-LF accumulation rate under the assumption that the initial age of laboratory- and pond-reared crabs was approximately 10 mo. This assumption is based on the observation that in July juveniles (mean CW $\sim 60 \mathrm{~mm}$ ) caught in the field had probably spawned in fall (September) of the previous year. Based on this assumption, the equation $\mathrm{LN}(\mathrm{LF}$ index $)=1.75 \times$ age $(\mathrm{yr})-3.65$ was significant $(\mathrm{p}<0.001)$ and explained $70 \%$ of the variation of the LN (or LF index) (Fig. 5).

Given the dependences on temperature of spawning date and thus seasonalized growth and LF accumulation rate, we tested the effect of shifting our assumption of spawning season to other dates, i.e. shifting fall (September 1997) and late-spring (June/July 1998) spawning to spring (May 1997) and fall (September 1998) spawning, respectively. In particular, the summer and fall period was of interest as warm waters might allow adequate growth before winter starts. Although initial time $\left(t_{0}\right)$ and initial LF level (LF intercept shifted $< \pm 20 \%$ ) changed, no significant differences resulted for growth coefficients and LF accumulation rates. It was also apparent that seasonal growth models most closely fit the absence of growth during winter months at low temperatures. These results support the contention that assumed ages for juveniles used for rearing studies closely correspond to true ages.

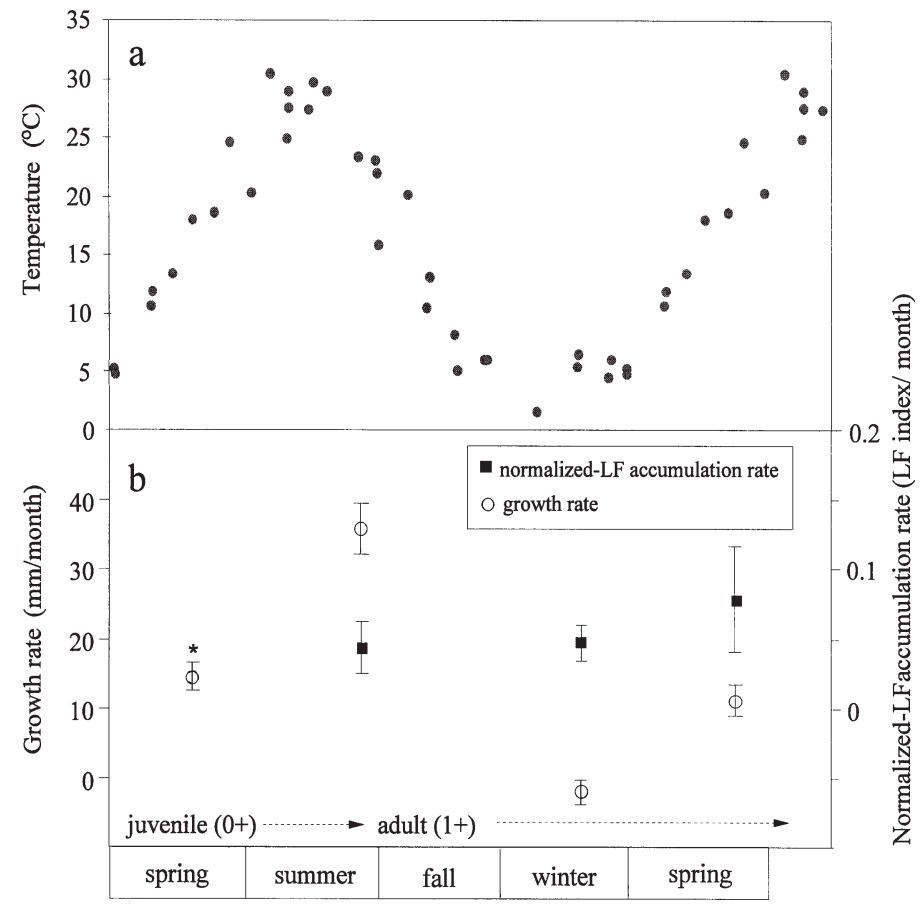

Fig. 2. (a) Mean surface water temperature of Choptank River from August 1998 to August 1999. (b) Seasonal growth of Callinectes sapidus (based on carapace width) and normalized-LF accumulation rate (no measure for the first spring season) estimated from 1998 and 1999 pond-reared crabs, each datum is mean $\pm 2 \mathrm{SE}_{i}$ *only this growth rate was estimated from 1999 and 2000 pond-reared crabs

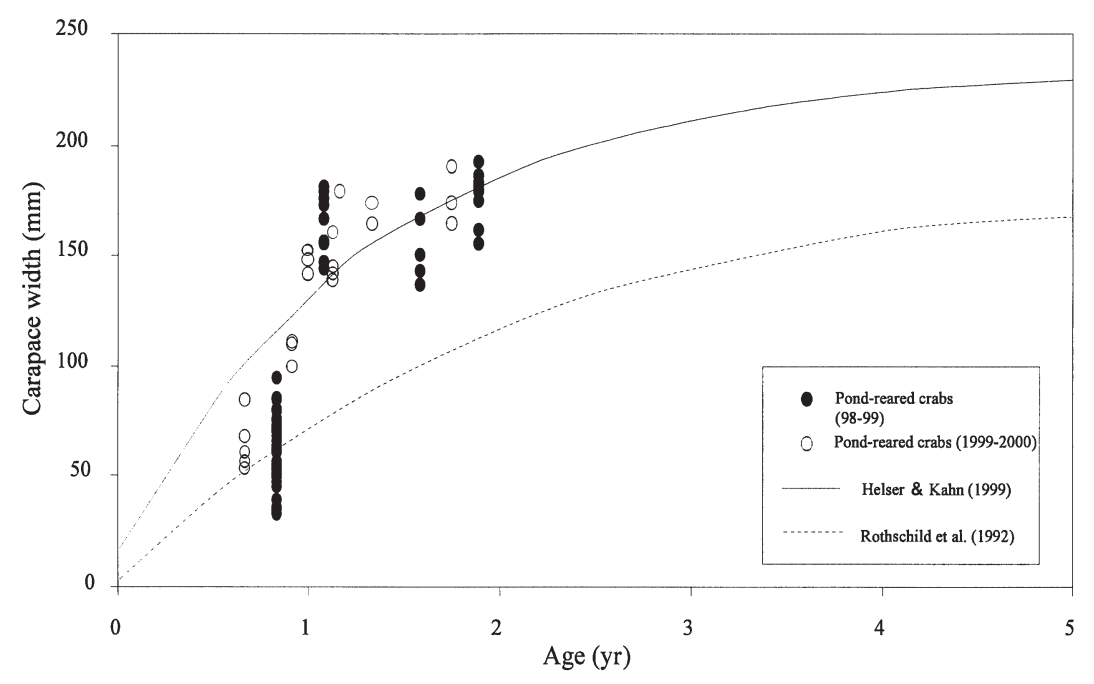

Fig. 3. Growth of pond-reared Callinectes sapidus ( $\mathrm{n}=3$ to 50 ) fitted with von Bertalanffy growth curves. Juveniles were introduced into ponds in August 1998 and March 1999. Growth curves are from Helser \& Kahn (1999) and Rothschild et al. (1992). Parameters of each growth curve are given in Table 1 


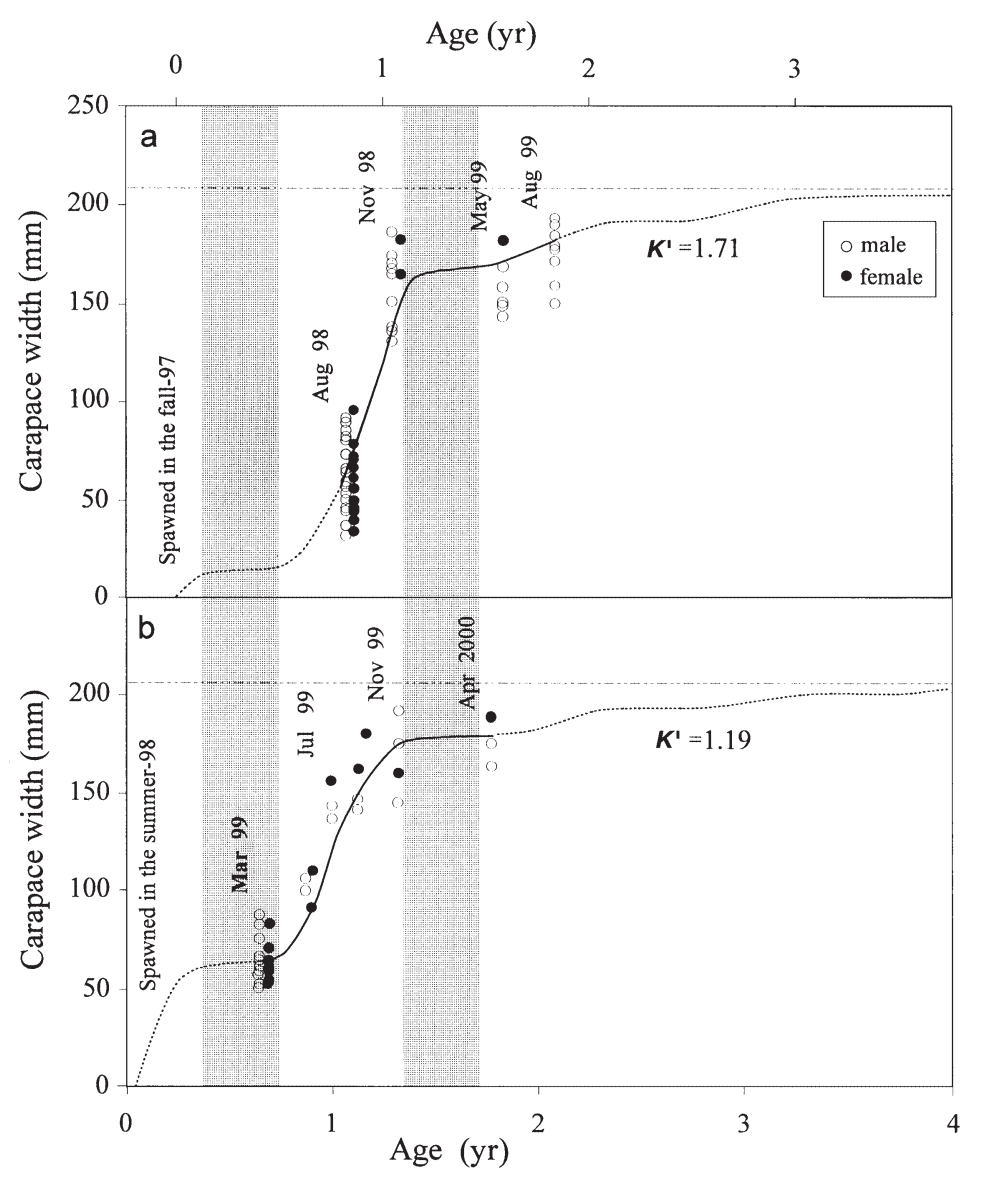

Fig. 4. Growth of pond-reared Callinectes sapidus with seasonalized von Bertalanffy growth curves. (a) Growth of crabs (assumed spawndates in September 1997) reared from August 1998 to August 1999; (b) growth of crabs (assumed spawn-dates in July 1998) reared from March 1999 to April 2000. For each age, date of sampling is shown and shaded grey areas indicate those times when no growth occurred (water temperature $\leq 10^{\circ} \mathrm{C}$ : Smith 1997). Parameters estimations of seasonalized von Bertalanffy functions (Eq. 1) modeled by carapace width (mm) are given in Table 2

\section{DISCUSSION}

In practice, bias in size-based growth rate estimates can lead to high uncertainty in Callinectes sapidus stock assessments. Growth rates estimated for pondreared crabs in the present study were significantly higher than those estimated in past rearing studies as well as those modeled for crab populations in the MidAtlantic region (see Table 1). Despite their amplitude, however, these rates probably reflect those likely to occur in nature. Because the ponds used for rearing crabs received a constant supply of Choptank River water, water quality was driven by seasonal and meteorological forcing. The ponds contained natural habitat structure (e.g. submerged aquatic vegetation) and forage assemblages (principally Fundulus spp.). Further, the growth coefficients of pond-reared crabs were similar to that estimated for Louisiana crabs (see Table 1). Although we do not know the effect of crab density on growth in the ponds, nor how forage conditions compared with those in the wild, we argue that empirical estimates derived from these systems represent robust patterns and amplitudes of seasonal and annual growth rates previously unavailable from laboratory or field studies on growth.

The pond-rearing experiments indicated that the von Bertalanffy growth model used extensively in the management of Chesapeake Bay blue crabs is imprecise for estimation of natural growth rates due to the strong seasonality of growth. Pond experiments also suggest that spawning date may influence growth rate. For example, crabs spawned during spring to early summer have a much longer initial growth season than late-summer- and fall-spawned crabs. Although their relative growth rate decreases during the second growth season, most attain harvestable size ( $>127 \mathrm{~mm} \mathrm{CW})$ during their second summer of life. Compared to the spring-spawned cohort (late-summer settlement), crabs which spawn in late summer and fall do not experience their first juvenile growth season until after winter. Because this cohort's exponential growth phase coincides with warm summer-time temperatures, higher growth rates are expected for the fall cohort than the spring cohort (now experiencing its second growth season). Thus, by fall of the second year of life, for both cohorts, CW may exceed minimal legal size. In the pond environment nearly all crabs exceeded this size. The growth rates observed for such pond-reared crabs may in fact be maximal, but we expect that $1+$ yr-old blue crabs comprise an important segment of late summer and fall landings (Ju 2000). A significant fraction of young crabs of harvestable size is consistent with an initial field study which indicated that $<2$ yr-old crabs recruited in substantial numbers to the fishery ( $\mathrm{Ju}$ et al. 1999). For current Chesapeake Bay blue crab stocks, age designations of $0+, 1+, 2+$ individuals have been assumed to correspond to crabs of $<60, \geq 60$ to $<120$, and $\geq 120 \mathrm{~mm} \mathrm{CW}$, respectively (Rugolo et al. 1998). Based upon observed growth dynamics in ponds, such age assignments may underestimate rates of recruitment into the harvestable population.

Biological reference points used to evaluate the effect of exploitation on population dynamics (Mace 1994) are quite sensitive to growth rates. For example, Helser \& Kahn (1999) reported that $F_{\max }$ and $F_{0.1}$ (2 reference 
points used to evaluate the rate of fishing mortality which will maximize yield at a given level of recruitment) were 2 times higher in Delaware Bay than in Chesapeake Bay due to different growth rate inputs $(K=0.75$ and 0.59 for Delaware and Chesapeake Bay blue crabs, respectively: see Table 1). The interpretation may be that a higher $\mathrm{K}$ coefficient results in increased recruitment into the harvestable population. However, model outputs of higher $F_{\text {max }}$ and $F_{0.1}$ were also affected by differing natural mortality rates and life span estimates between populations. Therefore, the yield per recruit analyses do not necessarily indicate that a population of faster growing individuals can withstand higher rates of fishing without collapse. Furthermore, it is important to recognize that while growth is a principal attribute in the production of blue crabs, other attributes such as sex ratio, settlement rates, overwinter mortality, and size-specific reproductive rates should be considered (Lipcius et al. 1995, Jivoff \& Hines 1998, Rugolo et al. 1998).

The LF index normalized using tissue protein reliably predicted chronological age in pond-reared crabs over the first $2 \mathrm{yr}$ of life and accurately resolved age differences $\geq 3$ mo. These results confirm that the LF index is well correlated with crab chronological age and compares well with previous laboratory results (Ju et al. 1999). More importantly, normalized-LF accumulation rates were not significantly different between crabs growing in laboratory or pond environments. The lack of a difference in LF accumulation rates between laboratory- and field-reared crayfish Cherax quadricarinatus was also observed by Sheehy (1992) using an histological approach for LF accumulation.

The normalized-LF accumulation rate in the blue crab appears largely unaffected by environmental conditions. This is despite predictions that the normalizedLF accumulation rate would be higher in pond- than in laboratory-reared crabs due to higher growth and associated metabolic rates of the former. This expectation was based upon evidence that LF accumulation rate is linked to physiological age which is a function of cumulative metabolic rate. One possible explanation may be that laboratory-reared crabs did not experience lower metabolic rates than crabs reared under more natural conditions. Metabolic rates of laboratoryreared crabs may have been high due to stress (limitation of food, space, or food quality) rather than anabolism (Sohal \& Donato 1978, Porta 1987). It is also interesting that normalized-LF accumulation rates in pond-reared crabs did not show seasonality, even though some studies have shown seasonal patterns of LF accumulation using the histological approach (Sheehy et al. 1994, Vila et al. 2000). It has been speculated that during summer months the rapid synthesis of protein-growing neural tissues may disproportionately exceed seasonal LF accumulation rates, masking LF accumulation (e.g. a growth dilution effect) (Hill \& Womersley 1991, Ju et al. 1999, Strauss 1999). Further, the metabolic rate of blue crabs is related to water temperature but not in a strictly linear fashion (Leffler 1972). However, the result from our additional laboratory-holding experiment for adult crabs (>130 mm $\mathrm{CW})$, which were held at different temperatures $\left(19^{\circ} \mathrm{C}\right.$ vs $7^{\circ} \mathrm{C}$ ) for $2 \mathrm{mo}$, indicated that temperature is a significant factor affecting LF accumulation in blue crabs (Ju 2000). The importance of temperature should be considered when applying empirical LF accumulation rates to natural crab populations, given the protracted spawning seasons of blue crabs and the temporal and spatial variations of temperature in coastal waters. More detailed study is required to fully understand the role of temperature on LF accumulation.

The exponential accumulation rate of the LF index (Fig. 5) suggests that LF is retained as a cumulative product through the life span of the crab. In other studies, this relationship has not been seen consistently (Hill \& Womersley 1993) and we observed that the 
accumulation rate declined slightly at the end points of the experiment (Fig. 5). This change may occur late in the crabs' life when growth slows and halts, and it has been suggested that decreases in LF accumulation rate in older individuals might be associated with reduced growth rate and metabolism (Lockwood 1968, Sheehy 1992). Because we have not yet investigated crabs $\geq 3 \mathrm{yr}$ of age, we cannot confidently extrapolate the normalized-LF accumulation rate for blue crabs to their entire life span.

Although it is clear that fundamental differences existed between the laboratory and the ponds in terms of blue crab growth rate, these differences did not substantially affect normalized-LF accumulation. The results confirm that protein-based LF measures can provide a robust method for age estimation of Callinectes sapidus through the first $2 \mathrm{yr}$ of life. Little is known about the longevity, growth dynamics and LF accumulation rates for crabs $\geq 3 \mathrm{yr}$, but this could be addressed using similar approaches.

Acknowledgements. The authors thank Troy Gunderson and Steve Larsen for technical assistance and Brenda Yates for manuscript preparation. M. E. Harvey, S. M. Harvey, M. R. Harvey, and Harrie Ju are thanked for assistance with crab collections. Comments by M. Fogarty on an early version greatly improved the manuscript, and Steve Cadrin and 2 anonymous reviewers substantially improved the final manuscript. This study was funded by NOAA grant NA76FU0560 through the Chesapeake Bay Program. The views expressed are those of the authors and do not necessarily reflect the views of NOAA or any of its subagencies. Contribution No. 3514 of the University of Maryland Center for Environmental Science.

\section{LITERATURE CITED}

Belchier MP, Shelton M, Chapman CJ (1994) The identification and measurement of fluorescent age-pigment abundance in the brain of a crustacean (Nephrops norvegicus) by confocal microscopy. Comp Biochem Physiol B 108: 157-164

Belchier M, Edsman L, Sheehy MRJ, Shelton PM (1998) Estimating age and growth in long-lived temperate freshwater crayfish using lipofuscin. Freshw Biol 39: 439-446

Clarke A, Kendall MA, Gore DJ (1990) The accumulation of fluorescent age pigments in the trochid gastropod Monodonta lineata. J Exp Mar Biol Ecol 144:185-204

Curry GL, Feldman RM (1987) Mathematical foundations of population dynamics. Texas A\&M University Press, College Station, TX

Ettershank G, George RY (1984) A new approach to the assessment of longevity in the Antarctic krill Euphausis superba. J Crustac Biol 4:295-305

Fannaly MT (1978) A method for tagging immature blue crabs (Callinectes sapidus Rathbun). North East Gulf Sci 2: 124-126

Fisher MR (1999) Effect of temperature and salinity on size at maturity of female blue crabs. Trans Am Fish Soc 128: 499-506
Fitz HC, Wiegert RG (1991) Tagging juvenile blue crabs, Callinectes sapidus, with microwire tags: retention, survival, and growth through multiple molts. J Crustac Biol 11: 229-235

Gayanilo FC Jr, Sparre P, Pauly P (1996) FAO/ICLARM stock assessment tools (FiSAT). FAO, Rome

Gutteridge JMC (1987) Oxygen radicals, transition metals and aging. In: Totaro EA, Glees P, Pisanti FA (eds) Advances in the biosciences, Vol 64. Pergamon Press, Oxford, p 1-22

Helser TE, Kahn DM (1999) Stock assessment of Delaware Bay blue crab (Callinectes sapidus) for 1999. Delaware Division of Fish \& Wildlife, Dover, DE

Hill KT, Womersley C (1993) Interactive effects of some environmental and physiological variables on fluorescent age pigment accumulation in brain and heart tissues of an aquatic poikilotherm. Environ Biol Fish 37:397-405

Hjort J, Lea E (1914) The age of a herring. Nature 94:255-256

Jivoff P, Hines AH (1998) Female behaviour, sexual competition and mate guarding in the blue crab, Callinectes sapidus. Anim Behav 55:589-603

Johnson DR (1995) Wind forced surface currents at the entrance to Chesapeake Bay: their effect on blue crab larval dispersion and post-larval recruitment. Bull Mar Sci 57:726-738

Jones P, Heimbuch D, Stagg C (1983) Report of the workshop on blue crab stock dynamics in Chesapeake Bay. University of Maryland, Chesapeake Bay Biological Laboratory ES-01-83, Solomons, MD

Ju SJ (2000) Development and application of biochemical approaches for understanding age and growth in crustaceans. PhD thesis, University of Maryland, College Park, $\mathrm{MD}$

Ju SJ, Secor DH, Harvey HR (1999) Use of extractable lipofuscin for age determination of blue crabs Callinectes sapidus. Mar Ecol Prog Ser 185:171-179

Katz ML, Robison WG Jr, Herrmann RK, Groome AB, Bieri JG (1984) Lipofuscin accumulation resulting from senescence and vitamin E deficiency: spectral properties and tissue distribution. Mech Ageing Dev 25:149-159

Leffler CW (1972) Some effects of temperature on the growth and metabolic rate of juvenile blue crabs, Callinectes sapidus, in the laboratory. Mar Biol 14:104-110

Lipcius RN, van Montfrans J, Hines AH (1995) Population dynamics and fishery ecology of the blue crab. Bull Mar Sci 57:918-919

Littell RC, Milliken GA, Stroup WW, Wolfinger RD (1999) SAS system for mixed models. SAS Institute Inc, Cary, NC

Lockwood APM (1968) Aspects of the physiology of Crustacea. WH Freeman \& Company, San Francisco

Mace PM (1994) Relationships between common biological reference points used as thresholds and targets of fisheries management strategies. Can J Fish Aquat Sci 51: $110-122$

Millikin MR, Williams AB (1984) Synopsis of biological data on the blue crab, Callinectes sapidus Rathbun. NOAA Tech Rep NMFS 1:1-39

Nguyen RT, Harvey HR (1994) A rapid micro-scale method for the extraction and analysis of protein in marine samples. Mar Chem 45:1-14

Nicol S, Stolp M, Hosie GW (1991) Accumulation of fluorescent age pigments in a laboratory population of Antarctic krill Euphausis superba Dana. J Exp Mar Biol Ecol 146: 153-161

O'Donovan V, Tully O (1996) Lipofuscin (age pigment) as an index of crustacean age: correlation with age, temperature and body size in cultured juvenile Homanus gam- 
marus. J Exp Mar Biol Ecol 207:1-14

Porta EA (1987) Tissue lipoperoxidation and lipofuscin accumulation as influenced by age, type of dietary fat and levels of vitamin E in rats. In: Totaro EA, Glees P, Pisanti FA (eds) Advances in the biosciences, Vol 64. Pergamon Press, Oxford, p 37-52

Rothschild B, Ault J, Patrick E, Smith S and 6 others (1992) Assessment of the Chesapeake Bay blue crab stock. University of Maryland, Chesapeake Bay Biological Laboratory Ref. CB92-003-036, CEES 07-4-30307. Solomons, MD

Rugolo L, Knotts KS, Lange AM, Crecco VA (1998) Stock assessment of Chesapeake Bay blue crab (Callinectes sapidus Rathbun). J Shellfish Res 17:493-517

Secor DH, Dean JM, Campana SE (1995) Recent developments in fish otolith research. University of South Carolina Press, Columbia, SC

Sheehy MR (1992) Lipofuscin age-pigment accumulation in the brain of ageing field- and laboratory-reared crayfish Cherax quadricarinatus (von Martens) (Decapoda: Parastacidae). J Exp Mar Biol Ecol 161:79-89

Sheehy MR, Greenwood JG, Fielder DR (1994) More accurate chronological age determination of crustaceans from field situations using the physiological age marker, lipofuscin. Mar Biol 121:237-245

Sheehy MR, Cameron E, Marsden G, McGrath J (1995) Age structure of female giant tiger prawns Penaeus monodon as indicated by neuronal lipofuscin concentration. Mar Ecol Prog Ser 117:59-63

Sheehy MR, Shelton PMJ, Wickins JF, Belchier M, Gaten E (1996) Ageing the European lobster Homarus gammarus by lipofuscin in its eyestalk ganglia. Mar Ecol Prog Ser 143:99-111

Smith SG (1997) Models of crustacean growth dynamics, PhD thesis, University of Maryland, College Park, MD

Sohal RS (1981) Relationship between metabolic rate, lipofuscin accumulation and lysosomal enzyme activity during

Editorial responsibility: Kenneth Tenore (Contributing Editor), Solomons, Maryland, USA ageing in the adult housefly, Musca domestica. Exp Gerontol 16:347-355

Sohal RS, Donato H (1978) Effects of experimentally altered lifespans on the accumulation of fluorescent age pigments in the housefly, Musca domestica. Exp Gerontol 9:33-41

Strauss RE (1999) Brain-tissue accumulation of fluorescent age pigments in four poeciliid fishes (Cyprinodontiformes) and the estimation of 'biological age'. Growth Dev Aging 63:151-170

van Engel WA (1958) The blue crab and its fishery in Chesapeake Bay. Part I. Reproduction, early development, growth, and migration. Commer Fish Rev 20:6-17

van Montfrans J, Capelli J, Orth RJ, Ryer CH (1986) Use of microwire tags for tagging juvenile blue crabs (Callinectes sapidus Rathbun). J Crustac Biol 6:370-376

van Montfrans J, Peery CA, Orth RJ (1990) Daily, monthly and annual settlement patterns by Callinectes sapidus and Neopanope sayi megalopae on artificial collectors deployed in the York river, Virginia: 1985-1988. Bull Mar Sci 46:214-229

van Montfrans J, Epifanio CE, Knott DM, Lipcius RN and 7 others (1995) Settlement of blue crab postlarvae in western north Atlantic estuaries. Bull Mar Sci 57:834-854

Vila Y, Medina A, Megina C, Ramos F, Sobrino I (2000) Quantification of the age-pigment lipofuscin in brains of knownage, pond-reared prawns Penaeus japonicus (Crustacea, Decapoda). J Exp Zool 286:120-130

von Bertalanffy L (1938) A quantitative theory of organic growth. Hum Biol 10:181-213

Wahle RA, Tully O, O'Donovan V (1996) Lipofuscin as an indicator of age in crustaceans: analysis of the pigment in the American lobster Homarus americanus. Mar Ecol Prog Ser 138:117-123

Welch JM, Epifanio CE (1995) Effect of variations in prey abundance on growth and development of crab larvae reared in the laboratory and in large field-deployed enclosures. Mar Ecol Prog Ser 116:55-64

Submitted: May 2, 2000, 2000; Accepted: March 14, 2001

Proofs received from author(s): December 7, 2001 